Article

\title{
Effects of a Trench as a Moisture Harvesting Structure on the Biomass Production and Growth of Trees Planted to Restore Degraded Land, Southern Ethiopia
}

\author{
Shiferaw Alem, Petr Němec ${ }^{\mathbb{D}}$ and Hana Habrová *(D) \\ Department of Forest Botany, Dendrology and Geobiocoenology, Faculty of Forestry and Wood Technology, \\ Mendel University in Brno, Zemědělská 1, 61300 Brno, Czech Republic; xshifera@mendelu.cz (S.A.); \\ petr.nemec@mendelu.cz (P.N.) \\ * Correspondence: habrova@mendelu.cz; Tel.: +420-545-134-555; Fax: +420-545-212-293
}

Received: 23 October 2020; Accepted: 27 November 2020; Published: 30 November 2020

\begin{abstract}
Knowledge about the biomass productivity of trees planted in a rainwater harvesting structure, i.e., a trench $(T)$, relative to a normal pit $(P)$ on degraded land is scarce. The objective of this research paper is to compare the effect of $T$ with $P$ on the growth and biomass production of the Acacia saligna and Casuarina equisetifolia which were planted on degraded land. All the individual stems of both species in the $T$ and $P$, their diameters at breast height (DBH) and heights in 2016 and 2020 were measured. Species-specific allometric equations were used to quantify the biomass production of the studied species. The $t$-tests were used for data analysis; both A. saligna and C. equisetifolia individuals planted in the $T$ had higher DBH and height increment as compared with A. saligna and C. equisetifolia that were planted and grown in a $P$. The results also revealed significant differences on the mean DBH and height of $A$. saligna and C. equisetifolia planted in a $T$ and $P(p<0.05)$. Between 2016 and 2020, the total biomass (TB) of $A$. saligna planted in a $T$ and in a $P$ increased significantly $(p<0.05)$ on average by $25.5 \mathrm{~kg} /$ tree and $7.7 \mathrm{~kg} /$ tree, respectively $(p<0.05)$. Similarly, the mean TB values of the C. equisetifolia planted in a $T$ and a $P$ between 2016 and 2020 increased significantly $(p<0.05)$ by $28.9 \mathrm{~kg} /$ tree and $13.1 \mathrm{~kg} /$ tree, respectively. Finally, establishing trenches to restore degraded lands was shown to facilitate growth and biomass production of planted species on degraded land.
\end{abstract}

Keywords: conservation structures; degraded land; dry biomass; soil moisture; restoration; semi-arid region; Casuarina equisetifolia; Acacia saligna

\section{Introduction}

Land degradation is a broad term and is defined as the temporary or permanent decline in the productive capacity of land resources to perform essential functions and services, which decreases land biological productivity and/or usefulness to humans [1,2]. Land degradation problems may occur through different physical, chemical, and biological processes that are induced naturally and/or by human activities such as deforestation, shifting cultivation, overgrazing, steep-slope farming, and overuse of chemical fertilizers and forest resources [3]. These problems prevent land from functioning effectively within an environmental system, which poses a major long-term challenge to humans in terms of adverse impacts on biomass productivity, food security, biodiversity, and environmental sustainability $[1,4,5]$. Land degradation is becoming a major problem in many regions of the world, especially in arid and semi-arid regions, and it affects the ability of land resources to perform essential ecosystem services and functions by indirectly affecting the type of plant grown in an area, reducing the availability of potable water, decreasing volumes of surface water, depleting aquifers, and causing biodiversity loss [6-12]. 
Problems related to land degradation can be prevented by using various mechanisms and activities [13], such as maximizing vegetation cover in degraded lands which should be given a priority since this action can prevent erosion and replace soil nutrients removed by erosion $[4,14,15]$. However, to maximize vegetation cover through natural regeneration and artificial plantations, factors such as shortages in soil nutrients and limited available water during the dry season in degraded lands affect the restoration process $[16,17]$. To enhance tree growth and facilitate natural regeneration, studies recommend placing different soil and water conservation structures in degraded lands, as it is assumed that these structures can improve soil water by improving infiltration and soil nutrients [16,18-20]. Establishing different soil and water conservation structures in degraded lands can play an important role in supplying water directly to the root zone and in reducing the sediment load and erosion at downstream sites [21]. Increasing soil water availability in degraded lands, especially in dry seasons, promotes the survival and growth rate of planted juvenile tree seedlings, while soil water limitations may increase seedling mortality and limit the growth of trees [22].

Research has shown that implementing rainwater harvesting structures in degraded lands increased water supplies, vegetation cover, and facilitated plant growth and biomass production [18,20,23-26]. Although many rainwater harvesting structures are used to conserve soil and water in degraded lands, research findings have shown variability in their effectiveness for plant growth, biomass production, restoration of degraded lands, etc. $[14,21,24,27]$. This result shows that the extent to which different soil and water conservation structures influence plant growth and rehabilitation on severely degraded lands needs to be further investigated, as their effect could vary depending on the severity of the degraded land, precipitation pattern, and the type of planted species used for restoration. In addition to this, the different pieces of research conducted on the impacts of rainwater harvesting structures on the growth of trees were performed at a plot level $[14,21,24,27]$, which is confined to a small space in an experimental area. However, findings on the impact of moisture harvesting structures on large scale degraded land restoration projects on the growth performance of trees are scant. The objectives of this research paper are (1) to evaluate the impact of water harvesting structures, mainly trenches established at the back of a tree-planting pit $(T)$, on the growth and dry biomass production of Acacia saligna (Labill.) H.L.Wendl and Casuarina equisetifolia L. relative to the same species planted in a normal pit $(P)$ on degraded land and (2) to compare and contrast the performances of $A$. saligna and C. equisetifolia on degraded land planted in a $T$ and $P$. At the beginning of the study, it was hypothesized that trees planted in a $T$ would achieve better growth and dry biomass production than the same species planted only in a $P$ that was not supported by a trench.

\section{Materials and Methods}

\subsection{Description of the Project and Study Area}

This study was part of a project supported by the Czech Development Agency, which was implemented by Mendel University in Brno, Czech Republic. The purpose of the project was to restore degraded land through physical and biological soil and water conservation measures for the benefit of the local community by reducing flooding problems and also to keep water for the dry season. With afforestation activities on the degraded land, the project established water harvesting structures, that is, a trench $\left(50 \mathrm{~cm}\right.$ depth $\times 50 \mathrm{~cm}$ width $\times 1 \mathrm{~m}$ in length $\left.=0.25 \mathrm{~m}^{3}\right)$, to reduce the runoff water and to facilitate the recharge of water into the ground. Downhill, which is approximately $25 \mathrm{~cm}$ away from the trench, a normal tree planting pit was prepared and used for seedling planting (Figure 1a). Similarly, in some areas of the degraded land, only normal plantation pits (without any water harvesting structures), were established for seedling planting purposes (Figure 1b). The seedlings of A. saligna and C. equisetifolia were planted in July 2012 in the $T$ and $P$. Both species planted and grown in a $T$ and $P$ were planted randomly and in a mixture. 


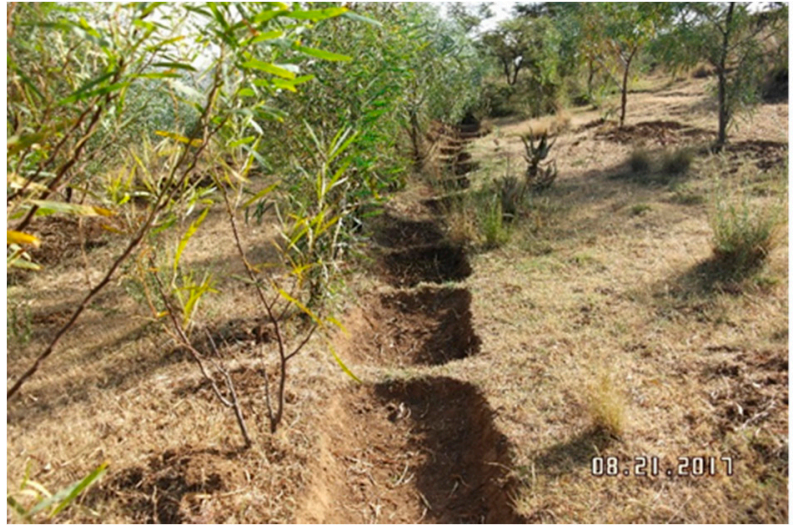

(a)

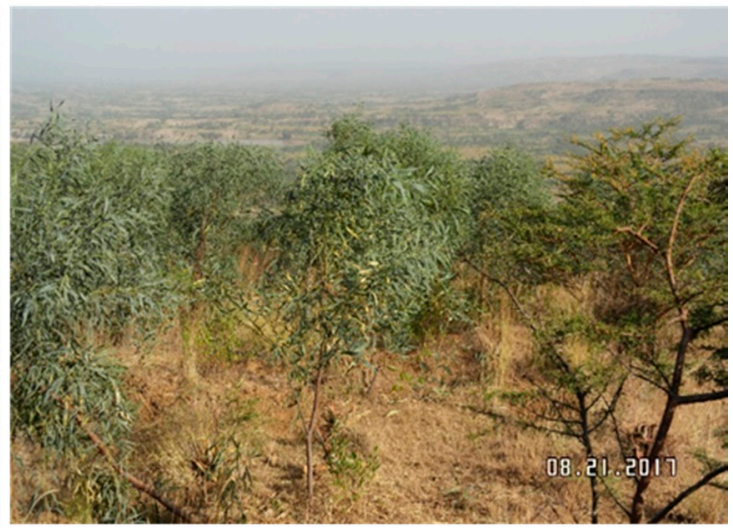

(b)

Figure 1. Acacia saligna trees grown in the trenches (a), originally $50 \mathrm{~cm}$ deep, $50 \mathrm{~cm}$ width, and $1 \mathrm{~m}$ long, and in the pits (b).

The project area is located in Kajimma Umbullo Kebele, Hawassa Zurya Wereda, Sidama region, Ethiopia. Geographically, it is located at $7^{\circ} 1^{\prime} 45^{\prime \prime} \mathrm{N}$ and $38^{\circ} 16^{\prime} 30^{\prime \prime} \mathrm{E}$, and it is at an altitude of $1700 \mathrm{~ms}$ above sea level. The nearest meteorological data recorded in Hawassa municipality, $20 \mathrm{~km}$ away from the study site, show that the area receives bimodal rainfall, and it has a mean annual rainfall of $959 \mathrm{~mm}$ per year (Figure 2). Soils are eutric and haplic cambisols [28]. Because of the loss of vegetation cover and overgrazing problems, the soil is exposed to erosion, and as a result, the topsoil of the study area is severely degraded; therefore, it has very poor soil nutrients and was an inhospitable place for plant growth [28].

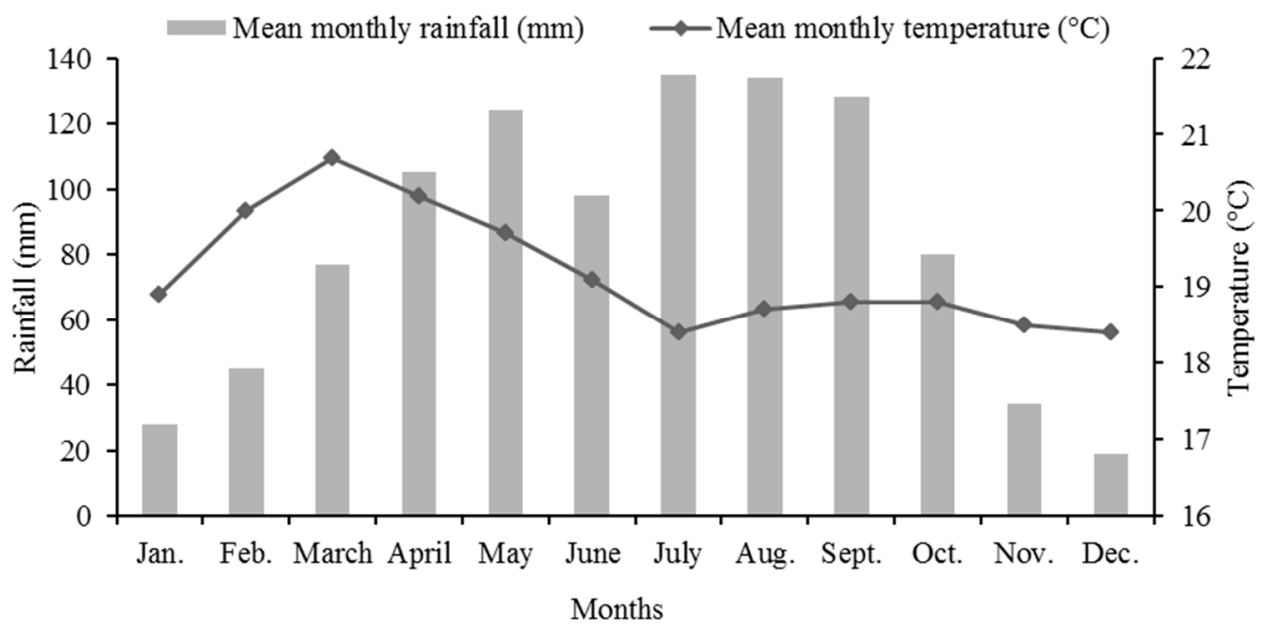

Figure 2. Mean monthly rainfall $(\mathrm{mm})$ and temperature $\left({ }^{\circ} \mathrm{C}\right)$ of Hawasa, Ethiopia.

\subsection{Data Collection}

All the trees of A. saligna and C. equisetifolia that were planted in the degraded land in the $T$ and $P$ and their diameters at breast height (DBH) at $1.3 \mathrm{~ms}$ above the ground were measured using a calliper. The heights of all the trees were also measured using a metre stick. The height and DBH data of the trees were measured in 2016 and 2020. The total number of measured tree stems of the species in the different years that were grown in a $T$ and $P$ is presented in Figure 3. The reason for the reduction in the number of trees measured in 2020 relative to 2016 was associated with the trees that were cut by the local communities. 


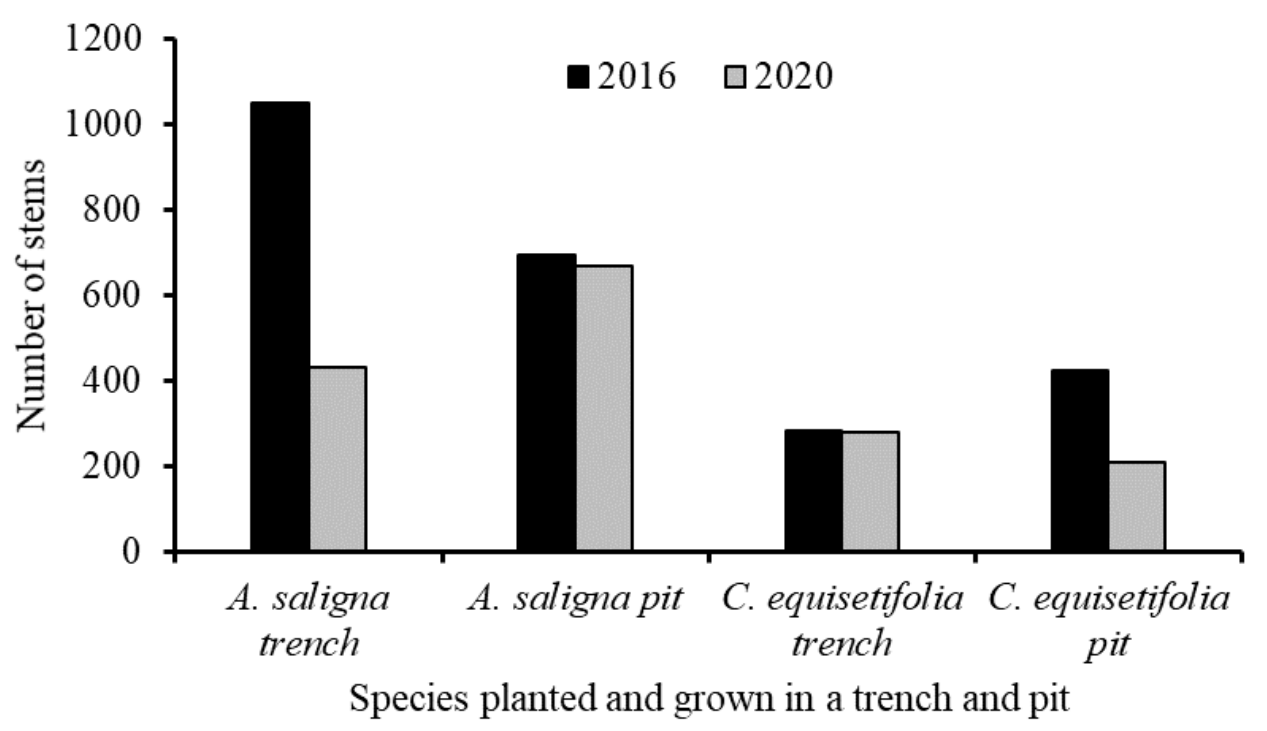

Figure 3. Number of measured stems by their diameters at breast height (DBH) and height in 2016 and 2020 that were planted in 2012 and grown in a trench and pit only.

\subsection{Data Analysis}

For the biomass data analysis, i.e., aboveground biomass (AGB) and belowground biomass (BGB), species-specific allometric equations were used. Hence, for the quantification of $A$. saligna AGB and BGB, the species-specific allometric Equations (1) and (2) developed by Jonson and Freudenberger [29] were used. Similarly, for the quantification of C. equisetifolia AGB and BGB, the species-specific allometric Equations (3) and (4) developed by Vidyasagaran and Paramathma [30] were used. The total biomass (TB) of the studied species was analysed by summing the AGB and BGB (Equation (5)).

$$
\begin{gathered}
\operatorname{Ln}(A G B)=-2.01+2.341 \operatorname{Ln}(D B H) \\
\operatorname{Ln}(B G B)=-2.525+1.815 \operatorname{Ln}(D B H) \\
\operatorname{Ln}(A G B)=-2.495 L N(D B H)-1.875 \\
\operatorname{Ln}(B G B)=-2.4517 L N(D B H)-3.35 \\
T B=B G B+A G B
\end{gathered}
$$

The statistical software program SigmaPlot 13 (Systat Software, Inc., San Jose, CA, USA) was used in the analysis. The data was evaluated for its normality assumption and it was found fulfilling the normality distribution. The normality of the data was evaluated using a Shapiro-Wilk test, and then the data was analysed using a $t$-test with the significance level of $p=0.05$.

\section{Results}

\subsection{Growth of Trees}

The mean DBH measured in 2016 and 2020 for the $A$. saligna species planted in the $T$ was relatively higher $(7.0 \mathrm{~cm}$ and $9.8 \mathrm{~cm})$ than the mean DBH of $A$. saligna grown in the $P$ only $(6.1 \mathrm{~cm}$ and $6.8 \mathrm{~cm})$. Hence, between 2016 and 2020, the mean DBH increased significantly by $2.8 \mathrm{~cm}$ and $0.7 \mathrm{~cm}$, respectively (Figure $4 \mathrm{~A}, \mathrm{C}, p<0.05$ ). This was supported by the $t$-test showing significant differences (Figure $4 \mathrm{~A}, \mathrm{C}$, $p<0.05)$. The mean heights of the $A$. saligna trees planted in the $T$ were $4.2 \mathrm{~m}$ in 2016 and $4.9 \mathrm{~m}$ in 2020 , while the mean heights of $A$. saligna planted in the pit had a mean height of $3.8 \mathrm{~m}$ in 2016 and $3.9 \mathrm{~m}$ in 2020, respectively. This shows that the mean height of $A$. saligna planted in the $T$ was higher than the mean height of the $A$. saligna trees planted and grown only in the $P$ (Figure $5 \mathrm{~A}, \mathrm{C}$ ). The mean height of 
A. saligna measured in 2016 and 2020 showed significant differences between the trees planted in the $T$ and $P$ (Figure $5 \mathrm{~A}, \mathrm{C}, p<0.05$ ).

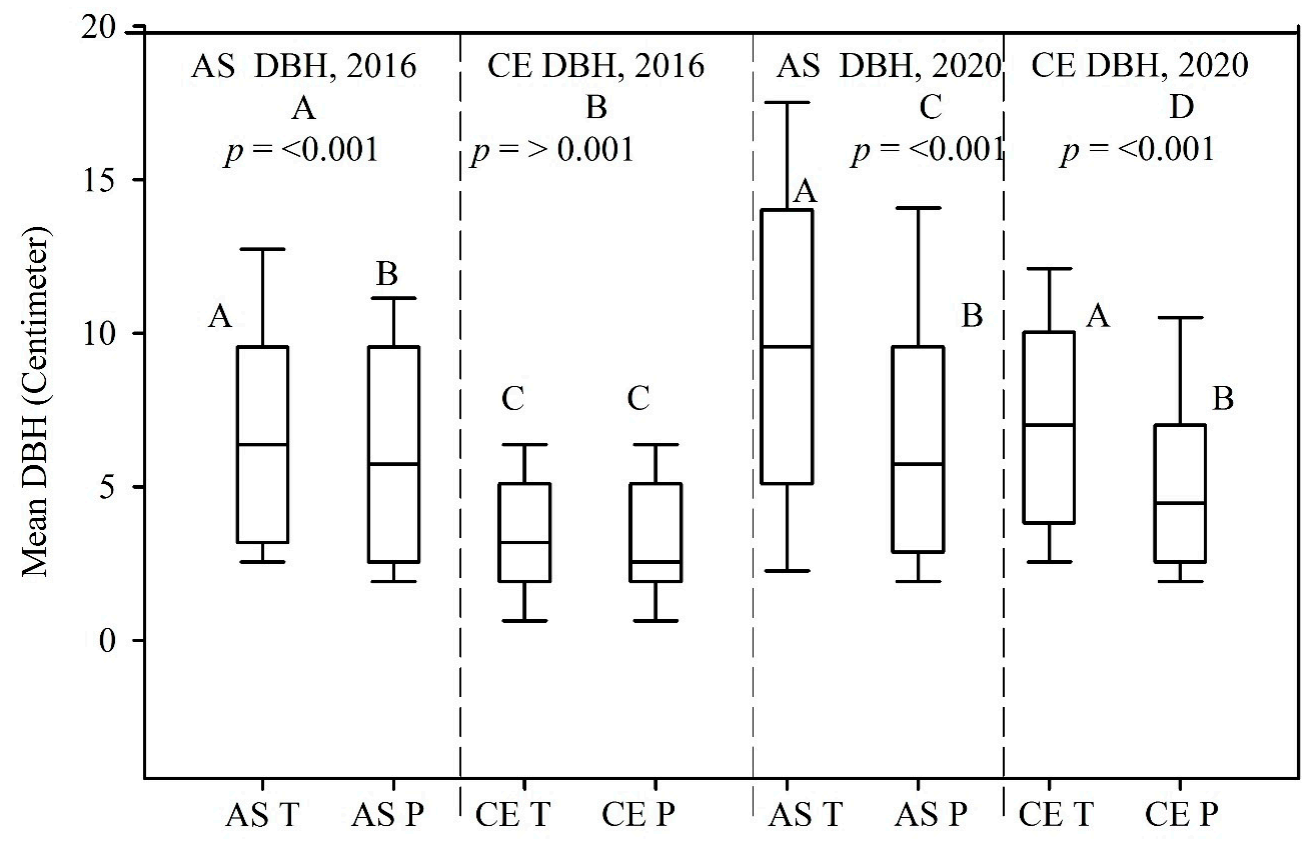

Tree species planted in a Trench (T) and Pit (P)

Figure 4. Mean DBH of A. saligna (AS) and C. equisetifolia (CE) in 2016 (A,B) and 2020 (C,D) planted and grown in a trench $(T)$ and a pit $(P)$. Grouping letters are given above the bars (species-wise comparisons via $t$-test at $p=0.05)$.

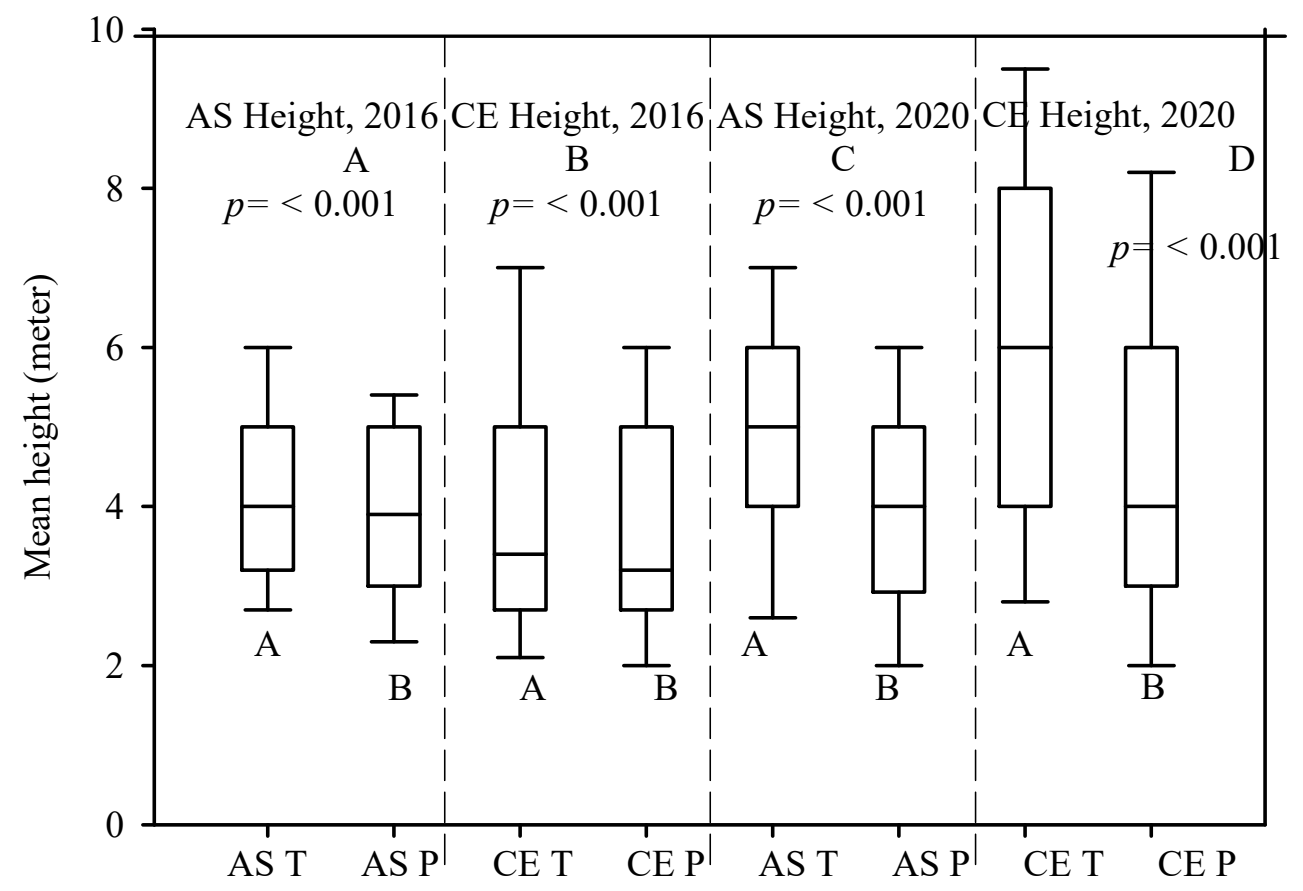

Tree species planted in a Trench $(\mathrm{T})$ and Pit $(\mathrm{P})$

Figure 5. Mean height of A. saligna (AS) and C. equisetifolia (CE) in 2016 (A,B) and 2020 (C,D) planted and grown in a trench $(T)$ and a plantation pit $(P)$. Grouping letters are given above the bars (species-wise comparisons via $t$-test at $p=0.05$ ). 
The mean DBH and height of $C$. equisetifolia planted in $T$ and $P$ are presented in Figures 4 and 5 , respectively. No significant differences between the mean DBH of $C$. equisetifolia planted in the $T$ and $P$ measured in 2016 (Figure $4 \mathrm{~B}, p>0.05$ ) were proved according to statistical analysis. However, the statistical analysis revealed significant differences between the mean DBH of $C$. equisetifolia planted in $T$ and $P$ (Figure $4 \mathrm{D}, p<0.05$ ) measured in 2020. The results further indicated that between 2016 and 2020, the DBH of C. equisetifolia planted in the $T$ and $P$ increased on average by $3.5 \mathrm{~cm}$ and $1.8 \mathrm{~cm}$, respectively. Similarly, between 2016 and 2020, the height of C. equisetifolia planted in $T$ and $P$ increased on average by $1.8 \mathrm{~m}$ and $1 \mathrm{~m}$, respectively. Significant differences between the mean heights of $C$. equisetifolia species planted in the $T$ and $P$ (Figure $5 \mathrm{~B}, \mathrm{D}, p<0.05$ ) appeared based on statistical analysis.

\subsection{Biomass Production}

Between 2016 and 2020, the mean AGB values of the A. saligna planted in the $T$ and $P$ increased by $22.7 \mathrm{~kg} /$ tree and $6.8 \mathrm{~kg} /$ tree, respectively. This indicates that the mean AGB values of the A. saligna planted in the $T$ were 3.3 times higher than the mean AGB values of the A. saligna planted in the $P$. Significant differences between the mean AGB values of the $A$. saligna planted and grown in the $T$ and the $P$ (Figures $6 \mathrm{E}$ and $7, p<0.05$ ) were proved in statistical analysis. The mean BGB values of the A. saligna for the 2016 and 2020 measurements, which were planted and grown in the $T$ and $P$, are presented in Figures 6 and 7, respectively. The results show that between 2016 and 2020, the mean BGB values of the $A$. saligna planted in the $T$ and $P$ increased by $2.8 \mathrm{~kg} /$ tree and $0.8 \mathrm{~kg} /$ tree, respectively. Significant differences in the BGB values of the A. saligna planted in the $T$ and $P$ (Figures 6 and 7 , $p<0.05)$ showed the statistical analysis.

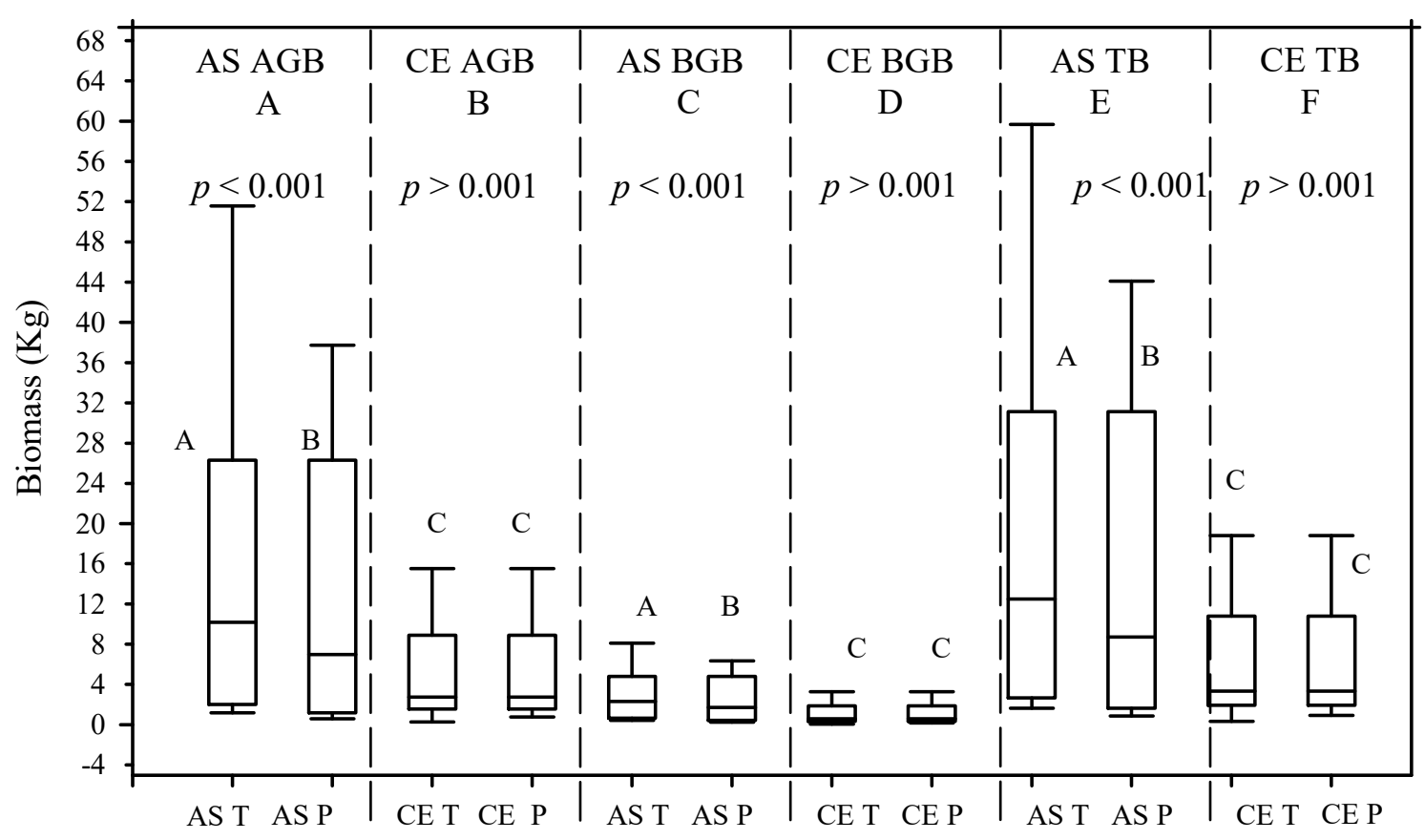

Tree species planted in a trench $(\mathrm{T})$ and pit $(\mathrm{P})$

Figure 6. Mean above-ground biomass (AGB), (A,B), belowground biomass (BGB), (C,D), and total biomass (TB), (E,F), of $A$. saligna (AS) and C. equisetifolia (CE) that were planted and grown in a trench ( $T$ ) and a plantation pit $(\mathrm{P})$ in 2016. Grouping letters are given above the bars (species-wise comparisons via $t$-test at $p=0.05)$. 


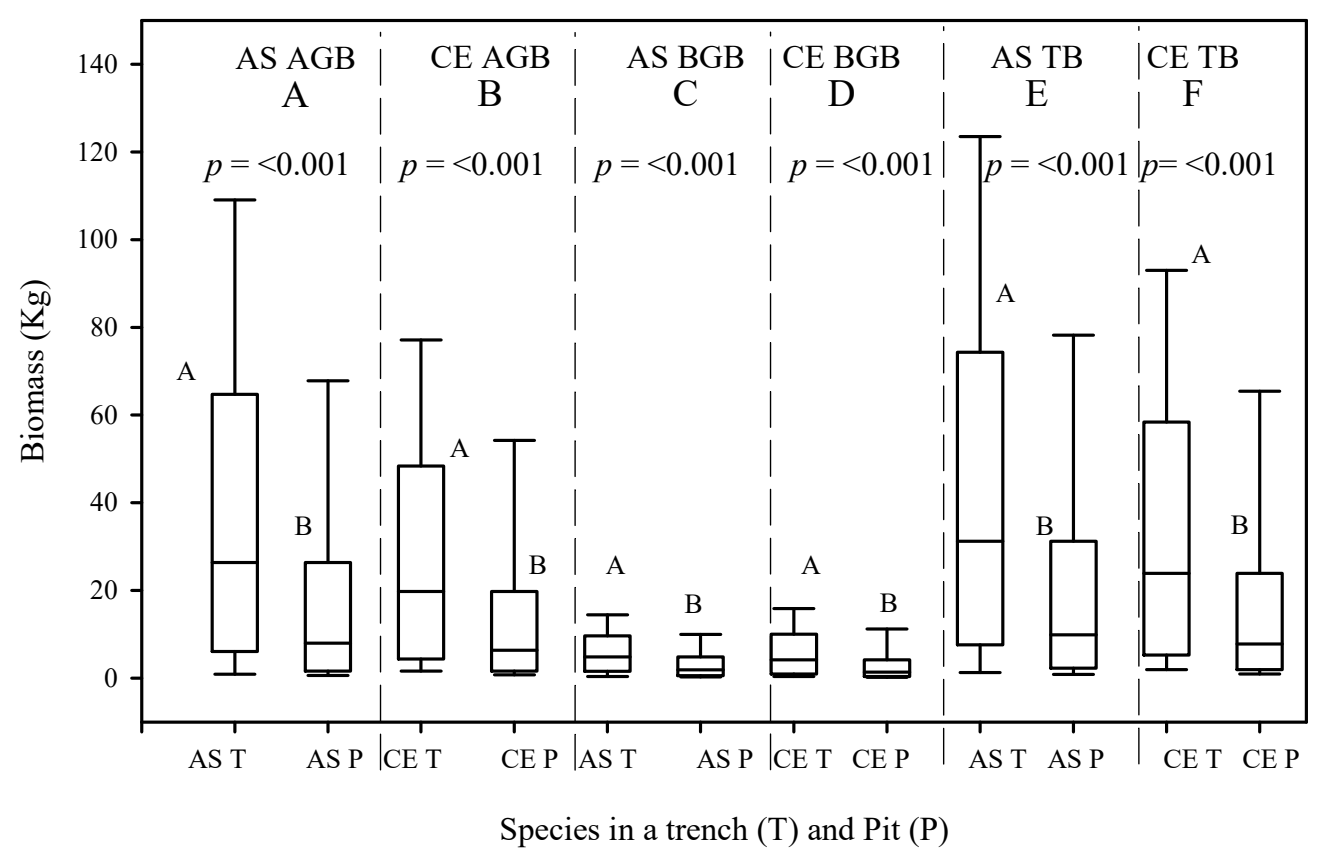

Figure 7. Mean above-ground biomass (AGB), (A,B), belowground biomass (BGB), (C,D), and total biomass (TB), (E,F), of $A$. saligna (AS) and C. equisetifolia (CE) planted and grown in a trench $(T)$ and a plantation pit $(P)$ in 2020. Grouping letters are given above the bars (species-wise comparisons via $t$-test at $p=0.05)$.

The mean AGB and BGB measurement results for the C. equisetifolia measured in 2016 and 2020 are presented in Figures 6 and 7, respectively. Between 2016 and 2020, the mean AGB values of the C. equisetifolia planted in the $T$ and $P$ increased by $24 \mathrm{~kg} /$ tree and $10.9 \mathrm{~kg} /$ tree, respectively. No significant differences between the mean AGB values of the C. equisetifolia planted in the $T$ and $P$ in 2016 (Figure 6B, $p>0.05$ ) were proved. However, the 2020 results indicated significant differences between the mean AGB values of the $C$. equisetifolia planted and grown in the $T$ and $P$ (Figure $7 \mathrm{~B}, p<0.05$ ). Between 2016 and 2020, the mean BGB values of the C. equisetifolia grown in the $T$ and $P$ increased by $4.9 \mathrm{~kg} / \mathrm{tree}$ and $2.2 \mathrm{~kg} /$ tree, respectively. The analysis for the 2016 measurements shows no significant differences between the BGB values of the C. equisetifolia planted and grown in the $T$ and $P$ (Figure $6 C, p>0.05$ ), however, the 2020 measurement results showed significant differences between the mean BGB values of the C. equisetifolia planted and grown in the $T$ and $P$ (Figure 7D, $p<0.05$ ).

The total biomass (TB) values of the A. saligna and C. equisetifolia planted in $T$ and $P$ for the 2016 and 2020 measurements are presented in Figure 6E,F and Figure 7E,F, respectively. Between 2016 and 2020, the mean TB values of A. saligna and C. equisetifolia that were planted and grown in the $T$ increased by $25.5 \mathrm{~kg} /$ tree and $28.9 \mathrm{~kg} /$ tree, respectively. In 2016-2020, the mean TB increases in A. saligna and C. equisetifolia planted in the $P$ were $7.7 \mathrm{~kg} /$ tree and $13.1 \mathrm{~kg} /$ tree, respectively. The 2016 results revealed significant differences between the TB values of the A. saligna grown in the $T$ and $P$ (Figure 6I, $p<0.001$ ) while there were no significant differences between the TB values of the $C$. equisetifolia grown in the $T$ and $P$ (Figure $6 \mathrm{~F}, p>0.001$ ). The analysis of data from 2020 revealed significant differences between the TB values of the $A$. saligna grown in the $T$ and $P$ (Figure 7E, $p<0.05$ ). Similarly, for the same year measurements of Casuarina equisetifolia, there were significant differences between the TB values in the $T$ and $P$ (Figure $7 \mathrm{~F}, p<0.05$ ).

\section{Discussion}

Degraded lands have limitations related to soil depth, nutrient deficiencies, moisture issues, etc., and for this reason, these lands are inhospitable for carrying out restoration activities [31]. The present study shows that both the A. saligna and C. equisetifolia species planted in the $T$ had relatively good 
growth (DBH and height increment) as compared with that of the same species planted and grown in the $P$. This could indicate that the moisture harvesting structure (trench) established in the degraded land served as one of the treatments to facilitate the growth of the planted species. Such a facilitation role of the trench in improving the growth and the biomass of the trees could be associated with its ability to trap runoff water and infiltrate it into the soil, which could help the planted trees utilize it for growth also during a substantial part of the dry season. Sumbal et al. [32] and Panigrahi et al. [33] described that soil moisture conservation structures reduce runoff and help the infiltration of rainwater during the rainy season. Rainwater is then available for plants during the dry period, which vigorously enhances plant growth and increases plant biomass compared with that of trees planted without moisture harvesting structures, i.e., planting pit only. Manivannan and Desai [34] reported that the performance of tree species increased in continuous trenches, which was attributed to increased moisture availability for the growth of plants. The present study result is in line with the findings of Sumbal et al. [32], who reported that Acacia auriculiformis planted with a soil and water conservation structure had better growth and productivity than those of species grown only in a tree-planting pit. Singh et al. [27] also reported that rainwater harvesting structures resulted in higher growth of Emblica officinalis on degraded land than in only a pit. Derib et al. [21] also found that compared with that planted in a normal pit, $A$. saligna species planted in a trench and eyebrow basin structures produced $68 \%, 95 \%$, and $52 \%$ increases in root collar diameter, $\mathrm{DBH}$, and height, respectively.

BGB and AGB values of $A$. saligna planted in the $T$ were greater than those planted only in the $P$. The rainwater harvesting structure therefore not only favours diameter and height increments in the studied species but also facilitates their biomass productivity on the degraded land. Singh [23], in a study on the restoration of degraded lands, recorded higher biomass production of Acacia catechu in a contour trench and V-ditch than in a plantation pit. Similarly, Kumer et al. [35] found that soil and water conservation measures such as terraces and trenches contributed to relatively high biomass production in Achras zapota trees. Our study results showed no significant differences between the biomass production of $A$. saligna and C. equisetifolia planted in the T. Similarly, there were no significant differences between the total biomass production of $A$. saligna and C. equisetifolia planted in the $P$. These results could further indicate that the two studied species performed equally on the degraded land of a semi-arid region. However, there were significant differences between the species planted in $T$ and $P$, which shows that the differences in the biomass values were much more influenced by the rainwater harvesting structure than the planted species. In contrast to the results of our study, Shone et al. [36] reported a variation in the performance of 45 native tree species on degraded land.

\section{Conclusions}

Based on the findings of the current study, it is concluded that establishing a moisture harvesting structure, a trench, facilitated the growth and biomass production of the two studied species planted on degraded land. The use of water harvesting structures within land degradation projects shows both rise of soil moisture as well as an increase in biomass production of set species. These facts support the reduction of soil erosion problems through an increase in vegetation cover. Finally, it is recommended that if A. saligna and C. equisetifolia are used for afforestation/restoration purposes on degraded land, then establishing the species with a rainwater harvesting structure will facilitate their growth and biomass production.

Author Contributions: Conceptualization S.A. and P.N.; methodology S.A. and H.H.; formal analysis S.A.; investigation S.A.; writing-original draft preparation S.A.; writing-review and editing P.N. and H.H.; project administration P.N. and H.H.; All authors have read and agreed to the published version of the manuscript.

Funding: This research was funded by Mendel University in Brno with contributions from the Czech Development Agency, grant numbers CzDA-ET-2010-13-31130, CzDA-GR-ET-2014-13-31220, and CzDA-ET-2019-001-DO-41040.

Acknowledgments: The authors are grateful to Eyasu Esheru, Tesfaye Hankamo, Alchamo Embakom, and Kenesa Chulka for their support of the fieldwork at the time of data collection.

Conflicts of Interest: The authors declare no conflict of interest. 


\section{References}

1. Zorn, M.; Komac, B. Land Degradation. In Encyclopedia of Natural Hazards; Bobrowsky, P.T., Ed.; Encyclopedia of Earth Sciences Series; Springer: Dordrecht, The Netherlands, 2013. [CrossRef]

2. Johnson, D.L.; Lewis, L.A. Land Degradation Creation and Destruction, 2nd ed.; Rowman and Littlefield Publishers INC.: Lanham, MD, USA, 2007; p. 307.

3. Acharya, A.K.; Kafle, N. Land degradation issues in Nepal and its management through agroforestry. J. Agric. Environ. 2009, 10, 115-123. [CrossRef]

4. Yirdaw, E.; Tigabu, M.; Monge, A. Rehabilitation of degraded dryland ecosystems-review. Silva Fenn. 2017, 51, 1673. [CrossRef]

5. Mueller, E.N.; Wainwright, J.; Parsons, A.J.; Turnbull, L. (Eds.) Patterns of Land Degradation in Drylands; Springer: London, UK, 2014; p. 383.

6. Mebrat, W. Natural regeneration practice in degraded high lands of Ethiopia through area enclosure. Int. J. Environ. Prot. Policy 2015, 3, 120-123. [CrossRef]

7. Bisaro, A.; Kirk, M.; Zdruli, P.; Zimmermann, W. Global drivers setting desertification research priorities: Insights from a stakeholder consultation forum. Land Degrad. Dev. 2014, 25, 5-16. [CrossRef]

8. Hueso-González, P.; Martínez-Murillo, J.F.; Ruiz-Sinoga, J.D. The impact of organic amendments on forest soil properties under Mediterranean climatic conditions. Land Degrad. Dev. 2014, 25, 604-612. [CrossRef]

9. Lieskovsky, J.; Kenderessy, P. Modelling the effect of vegetation cover and different tillage practices on soil erosion in vineyards: A case study in Vráble (Slovakia) using WATEM/SEDEM. Land Degrad. Dev. 2014, 25, 288-296. [CrossRef]

10. Srinivasarao, C.; Venkateswarlu, B.; Lal, R.; Singh, A.K.; Kundu, S.; Vittal, K.P.R.; Patel, J.J.; Patel, M.M. Long-term manuring and fertilizer effects on depletion of soil organic carbon stocks under pearl millet-cluster bean-castor rotation in Western India. Land Degrad. Dev. 2014, 25, 173-183. [CrossRef]

11. Hurni, H.; Solomon, A.; Amare, B.; Berhanu, D.; Ludi, E.; Portner, B.; Birru, Y.; Gete, Z. Land degradation and sustainable land management in the highlands of Ethiopia. In Global Change and Sustainable Development: A Synthesis of Regional Experiences from Research Partnerships; Hurni, H., Wiesmann, U., Eds.; Georaphica Bernensia: Bern, Switzerland, 2010; pp. 187-201.

12. Johnson, D.L.; Ambrose, S.H.; Bassett, T.J.; Bowen, M.L.; Crummey, D.E.; Isaacson, J.S.; Johnson, D.N.; Lamb, P.; Saul, M.; Winter-Nelson, A.E. Meanings of environmental terms. J. Environ. Qual. 1997, 26, 581-589. [CrossRef]

13. Gashaw, T.; Bantider, A.; Gebre-Silassie, H. Land degradation in Ethiopia: Causes, impacts and rehabilitation techniques. J. Environ. Earth Sci. 2014, 4, 98-104.

14. Siyum, G.E.; Tassew, T.; Gidey, A. Effect of different moisture harvesting techniques on seedling survivals and growth of trees in degraded lands of Southern Tigray. Asian J. Res. Agric. For. 2019, 4, 1-10. [CrossRef]

15. Coxhead, I.; Øygard, R. Land Degradation; Cambridge University Press: Cambridge, UK, 2007; pp. $146-161$. [CrossRef]

16. Gammoh, I.A. A mechanized system for establishment of forage shrubs in water harvesting micro-catchment structures. Int. J. Bot. 2011, 7, 145-153. [CrossRef]

17. Li, W.Q.; Liu, X.-J.; Khan, M.A.; Gul, B. Relationship between soil characteristics and halophytic vegetation in coastal region of north China. Pak. J. Bot. 2008, 40, 1081-1090.

18. Vohland, K.; Barry, B. A review of in situ rainwater harvesting (RWH) practices modifying landscape functions in African drylands. Agric. Ecosyst. Environ. 2009, 131, 119-127. [CrossRef]

19. Jia, Y.; Li, F.M.; Wang, X.L.; Yang, S.M. Soil water and alfalfa yields as affected by alternating ridges and furrows in rainfall harvest in a semiarid environment. Field Crop Res. 2006, 97, 167-175. [CrossRef]

20. Prinz, D. Water harvesting for afforestation in dry areas. In Proceedings of the 10th International Conference on Rainwater Catchment Systems, Mannheim, Germany, 10-14 September 2001; pp. 195-206.

21. Derib, S.D.; Assefa, T.; Berhanu, B.; Zeleke, G. Impacts of micro-basin water harvesting structures in improving vegetative cover in degraded hill-slope areas of north-east Ethiopia. Rangel. J. 2009, 31, 259-265. [CrossRef]

22. Yavitt, J.B.; Wright, S.J. Seedling growth responses to water and nutrient augmentation in the understorey of a lowland moist forest, Panama. J. Trop. Ecol. 2008, 24, 19-26. [CrossRef] 
23. Singh, G. Enhancing growth and biomass production of plantation and associated vegetation through rainwater harvesting in degraded hills in southern Rajasthan, India. New For. 2012, 43, 349-364. [CrossRef]

24. Ludwig, J.A.; Wilcox, B.P.; Breshears, D.D.; Tongway, D.J.; Imeson, A.C. Vegetation patches and run off erosion as interacting ecohydrological processes in semiarid landscapes. Ecology 2005, 86, 288-297. [CrossRef]

25. Yang, X.-h.; Wang, K.-q.; Wang, B.-r.; Yu, C.-t. Afforestation using micro-catchment water harvesting system with microphytic crust treatment on semi-arid Loess Plateau: A preliminary result. J. For. Res. 2005, 16, 9-14. [CrossRef]

26. Gupta, G.N. Rain water management for tree planting in Indian desert. J. Arid Environ. 1995, 31, $219-235$. [CrossRef]

27. Singh, G.; Khan, A.U.; Kumar, A.; Bala, N.; Tomar, U.K. Effects of rainwater harvesting and afforestation on soil properties and growth of Emblica officinalis while restoring degraded hills in western India. Afr. J. Environ. Sci. Technol. 2012, 6, 300-311. [CrossRef]

28. Tiki, L.; Tadesse, M. Impacts of integrating different soil and water conservation measures into hillside area closure on woody species composition and structure in Hawassa Zuria district, Ethiopia. Wudpecker J. Agric. Res. 2015, 44, 40-49.

29. Jonson, J.H.; Freudenberger, D. Restore and sequester: Estimating biomass in native Australian Woodland Ecosystems for their carbon-funded restoration. Aust. J. Bot. 2011, 59, 639-652. [CrossRef]

30. Vidyasagaran, K.; Paramathma, M. Biomass prediction of Casuarina equisetifolia, forest plantations in the west coastal plains of Kerala, India. Indian J. Sci. Res. Technol. 2014, 2, 83-89.

31. Mekonnen, Z. A holistic approach to the restoration of degraded natural resources: A review and synthesis. Res. J. Agric. Environ. Manag. 2013, 2, 58-68.

32. Sumbali, S.; Koppad, A.G.; Gurav, M. Effect of soil moisture conservation structures and application of manures and fertilizers on growth of Acacia auriculiformis. Int. J. Environ. Sci. 2012, 1, 178-185.

33. Panigrahi, B.; Panda, S.N.; Mal, B.C. Rainwater conservation and recycling by optimal size on-farm reservoir. Resour. Conserv. Recycl. 2007, 50, 459-474. [CrossRef]

34. Manivannan, S.; Desai, A.R. Effect of in-situ moisture conservation practices on runoff, soil loss and initial growth of cashew (Anacardium occidentale). Indian J. Soil Conserv. 2007, 35, 147-150.

35. Kumar, R.; Bhatnagar, P.R.; Kakade, V.; Dobhal, S. Tree plantation and soil water conservation enhances climate resilience and carbon sequestration of agro ecosystem in semi-arid degraded ravine lands. Agric. For. Meteorol. 2020, 282-283, 107857. [CrossRef]

36. Shono, K.; Davies, S.T.; Chua, Y.K. Performance of 45 native tree species on degraded lands in Singapore. J. Trop. For. Sci. 2007, 19, 25-34.

Publisher's Note: MDPI stays neutral with regard to jurisdictional claims in published maps and institutional affiliations.

(C) 2020 by the authors. Licensee MDPI, Basel, Switzerland. This article is an open access article distributed under the terms and conditions of the Creative Commons Attribution (CC BY) license (http://creativecommons.org/licenses/by/4.0/). 